\title{
Komposisi Dan Karateristik Jaringan Karkas Domba Ekor Tipis Yang Diberi Ransum Berbasis Indigofera zollingeriana Pada Sistem Pemeliharaan Yang Berbeda
}

\author{
Composition and Characteristic of Thin-tailed Sheep's Carcas Tissue Fed With Green \\ Concentrate Feed on The Different Nurture System
}

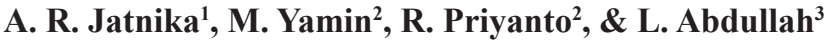 \\ ${ }^{1}$ Ilmu Produksi dan Teknologi Peternakan, Fakultas Peternakan, Institut Pertanian Bogor \\ ${ }^{2}$ Departmen Ilmu Produksi dan Teknologi Peternakan, Fakultas Peternakan, Institut Pertanian Bogor \\ ${ }^{3}$ Departemen Ilmu Nutrisi dan Teknologi Pakan, Fakultas Peternakan, Institut Pertanian Bogor \\ Jl. Agatis Kampus IPB Dramaga, Bogor 16680 \\ Email koresponden author: rezajatnika5@gmail.com
}

\begin{abstract}
This study aimed to find out the compoSItion and distribution of thin-tailed sheep's carcas tissue fed with green concentrate feed on the different breeding system. A total of 20 female thin-tailed sheep around 1 year old with an average initial weight of $18.3 \pm \mathbf{2 . 0 1}$, intenSIvely and semi-intenSIvely nurture for 119 days. Feed was given in the form of brachiaria humidicola grass and green concentrate with commercial concentrate as a control. Green concentrates and commercial concentrates are given in the morning at 07.00 and grass is given at 11.00 , with a ratio of $40: 60 \%$. Concentrates were given with different nurture systems was carried out with four treatments, namely five sheep grazed for 6 hours with commercial concentrate feed (SIKK), five sheep grazed for 6 hours with green concentrate feed (SIIZ), five sheep grounded with grass feed and commercial concentrates (IKK), and five sheep are grounded with grass feed and green concentrate (IIZ). The experiment was carried out in a completely randomized factorial pattern with $2 \times 2$ treatments and 5 replications with initial weights as a correction factor. The results showed that sheep that were given green concentrates had lower weight, carcass weight, lower fat weight compared to commercial concentrates. However, with semi-intenSIve nurture it produces weight and percentage of muscle that is not much different from sheep that are given commercial concentrates.
\end{abstract}

Keywords: thin tail sheep, carcass, green concentrate, nurture system.

\begin{abstract}
ABSTRAK
Penelitian ini bertujuan untuk mengetahui komposisi dan distribusi jaringan karkas domba ekor tipis yang diberi pakan konsentrat hijau pada sistem pemuliaan yang berbeda. Sebanyak 20 domba betina ekor tipis berusia sekitar 1 tahun dengan berat awal rata-rata 18.3 \pm 2.01 , pemeliharaan intensif dan semi intensif selama 119 hari. Pakan diberikan dalam bentuk rumput brachiaria humidicola dan konsentrat hijau sebagai konsentrat komersial. Konsentrat hijau dan konsentrat komersial diberikan pada pagi hari pukul 07.00 dan rumput diberikan pukul 11.00, dengan perbandingan 40:60\%. Konsentrat diberikan dengan sistem pengasuhan yang berbeda dilakukan dengan empat perlakuan, yaitu lima ekor domba yang digembalakan selama 6 jam dengan pakan konsentrat komersial (SIKK), lima ekor domba yang digembalakan selama 6 jam dengan pakan konsentrat hijau (SIIZ), lima ekor domba yang diberi pakan rumput dan konsentrat komersial (IKK), dan lima domba diberi pakan rumput dan konsentrat hijau (IIZ). Percobaan dilakukan dalam pola faktorial acak lengkap dengan perlakuan $2 \times 2$ dan 5 ulangan dengan bobot awal sebagai faktor koreksi. Hasil penelitian menunjukkan bahwa domba yang diberi konsentrat hijau memiliki bobot lebih rendah, bobot karkas, bobot lemak lebih rendah dibandingkan konsentrat komersial. Namun, dengan pemeliharaan semi-intensif menghasilkan berat dan persentase otot yang tidak jauh berbeda dari domba yang diberi konsentrat komersial.
\end{abstract}

Kata kunci: domba ekor tipis, karkas, konsentrat hijau, sistem pemeliharaan. 


\section{PENDAHULUAN}

Domba ekor tipis merupakan salah satu jenis domba lokal yang banyak dipelihara oleh peternak di Indonesia (Zulfahmi et al. 2016). Kelebihan dari domba ini adalah dapat hidup di daerah tropis, tahan terhadap pakan berkualitas rendah, umur dewasa kelamin yang relatif cepat serta tidak mudah terserang penyakit (Jarmuji, 2010). Pakan yang digunakan untuk meningkatkan produktifitas domba pada umumnya berupa konsentrat yang sudah dikomersialkan (Baihaqi et al. 2013). Penggemukan domba berbasis konsentrat sudah banyak dilakukan.

Wijaya et al. (2016) dan Santos (2018) melaporkan bahwa pemberian pakan berbasis konsentrat komersial dapat meningkatkan pertambahan bobot badan domba. Hal ini menyebabkan permintaan akan konsentrat semakin tinggi sehingga mengakibatkan harga konsentrat tersebut semakin meningkat pula. Tanaman Indigofera zollingeriana merupakan salah satu jenis legume yang dapat dijadikan sebagai pakan sumber protein selain konsentrat komersial. Tanaman ini mengandung protein kasar hingga $29.16 \%$, lemak kasar 3.62\%, serat kasar 14.02\% dan TDN 75-78\% (Abdullah et al. 2010), produksi bahan kering hingga 33.3 ton/ha/thn (Taringan et al. 2010), dan dapat hidup pada musim kering, salinitas dan di wilayah genangan air (Hassen et al. 2007). Tanaman ini diharapkan dapat dijadikan sebagai pakan alternatif dari konsentrat komersial yang harganya relatif mahal.

Pemeliharaan domba pada umumnya dilakukan dengan sistem pemeliharaan intensif dan semi intensif. Bila dilihat dari segi produktivitasnya, domba yang dipelihara secara semi intensif dengan pakan berbasis hijauan, memiliki tingkat perlemakan yang lebih rendah (Baihaqi et al. 2013), namun proporsi otot yang sama dengan yang dipelihara secara intensif (Pethick dan Rowe 1996) serta dapat mendukung efesiensi tenaga kerja (Sudaryanto dan Priyanto 2008).

Permintaan pasar akan daging rendah lemak semakin meningkat (Zubir et al. 2011), karena produk daging lebih lean sudah dijadikan sebagai salah satu faktor penilaian pada karkas (Johnson 2005 dan Rodrigues 2006). Hal ini terkait dengan isu kesehatan dari produk daging domba (Corcoran et al. 2001). Dari uraian tersebut, maka perlu dilakukan penelitian tentang komposisi dan distribusi jaringan karkas berbasis Indigofera zollingeriana pada domba ekor tipis yang dipelihara dengan sistem pemeliharaan yang berbeda.

\section{MATERI DAN METODE}

Waktu dan Tempat Penelitian

Penelitian ini dilaksanakan di Unit Pendidikan dan Penelitian Peternakan Jonggol (UP3J) dan di Laboratorium Ruminansia Kecil Departemen Ilmu Produksi dan Teknologi Peternakan Fakultas Peternakan Institut Pertanian Bogor. Penelitian ini dilaksanakan dari bulan September sampai dengan Desember 2018.

\section{Domba Ekor Tipis}

\section{Materi Penelitian}

Domba yang digunakan dalam penelitian ini adalah domba ekor tipis betina sebanyak 20 ekor dengan rata-rata bobot awal $18.3 \pm 2.01 \mathrm{~kg}$ dengan umur di bawah 1 tahun. Ternak domba diperoleh dari PT. Tawakkal Farm Kecamatan Caringin Kabupaten Bogor Jawa Barat.

\section{Indigofera zollingeriana dan Konsentrat Komersial}

Pakan yang digunakan dalam penelitian ini adalah Indigofera zollingeriana dalam bentuk tepung, sedangkan konsentrat komersial yang digunakan berasal dari PT. Tawakkal Farm yang berlokasi di daerah Caringin Jawa Barat. Kandungan nutrien Indigofera zollingeriana dan konsentrat komersial yang digunakan pada penelitian ini dapat dilihat pada Tabel 1.

\section{Prosedur Penelitian}

Indigofera zollingeriana dan konsentrat komersial diberikan sebanyak $40 \%$ dan rumput $B$. humidicola $60 \%$. Penimbangan sisa pakan dilakukan keesokan harinya. Setelah melalui masa adaptasi selama 1 bulan, dombadomba tersebut selanjutnya diberi perlakuan pakan dan sistem pemeliharaan yang berbeda selama 3 bulan. Perlakuan pakan dan sistem pemeliharaan yang berbeda dilakukan dengan ketentuan:

SIKK : lima domba digembalakan selama 6 jam dengan pemberian rumput dan konsentrat komersial

SIIZ : lima domba digembalakan selama 6 jam dengan pemberian rumput dan Indigofera zollingeriana

IKK : lima domba dikandangkan dengan pemberian rumput dan konsentrat komersial

IIZ : lima domba dikandangkan dengan pemberian rumput dan Indigofera zollingeriana

\section{Pemotongan dan penguraian karkas domba}

Domba yang disembelih ditimbang bobot badannya untuk mengetahui bobot potong. Pemotongan domba dilakukan selama 2 hari dengan jumlah pemotongan pada

Tabel 1. Kandungan nutrisi pakan Indigofera zollingeriana dan konsentrat komersial (\%)

\begin{tabular}{lccccccc}
\hline Jenis pakan & BK & Abu & PK & SK & LK & BETN & TDN \\
\hline Indigofera zollingeriana & 89.92 & 8.34 & 13.59 & 22.56 & 0.53 & 44.90 & 59.31 \\
Konsentrat komersial & 84.33 & 11.61 & 13.03 & 15.15 & 1.18 & 42.96 & 54.76 \\
Rumput Brachiaria humidycola & 90.39 & 5.88 & 5.74 & 32.65 & 1.20 & 44.92 & 56.58 \\
\hline
\end{tabular}

Keterangan : $\mathrm{BK}=$ bahan kering; $\mathrm{PK}=$ protein kasar; $\mathrm{SK}=$ serat kasar; $\mathrm{LK}=$ lemak kasar, Beta-N =bahan ekstrak tanpa nitrogen, $\mathrm{TDN}=$ total digestible nutrient. 
hari pertama adalah 12 ekor sebagai perwakilan dari setiap perlakuan, dan hari berikutnya 6 ekor. Proses pemotongan (penyembelihan) ternak menurut MUI (2009) dan penguraian karkas domba mengikuti petunjuk dari Herman (1993). Pemotongan dilakukan dengan cara memotong pada area leher yang terfokus pada bagian arteri karotis, vena jugularis, oesofhagus, trachea.

Sebelum dikuliti, terlebih dahulu domba tersebut dilepaskan kepalanya dari tubuh, tepat di daerah sendi occipito-atlantis. Kaki depan dan kaki belakang dipotong tepat pada sendi carpo-metacarpal dan sendi tarsometatarsal. Kemudian domba digantung pada bagian tendon kaki belakang (tendon achilles) untuk mempermudah pengkulitan. Kulit dituris dari anus hingga leher pada bagianbagian perut dan dada, selanjutnya dari arah kaki belakang dan kaki depan menuju irisan pertama, serta seluruh bagian karkas. Selanjutnya jeroan dikeluarkan dengan penyayatan mulai dari bagian perut sampai dada, rectum dipisahkan dan diikat untuk mencegah keluarnya feses. Setelah organ dalam, lemak omental, ginjal dan ekor dipisahkan maka didapatkan bobot karkas panas yang kemudian disimpan dalam ruang pendingin (chiller) dengan suhu $4^{\circ} \mathrm{C}$ selama 24 jam. Karkas yang sudah dimasukan di dalam ruang pendingin (chiller) kemudian dilakukan penilaian konformasi karkas (butt shape).

Selanjutnya karkas tersebut dibelah menjadi dua bagian sepanjang tulang belakang dari leher (ossa vertebrae cervicalis) sampai pangkal leher (ossa vertebrae sacralis). Masing-masing bagian karkas kiri dan kanan yang sudah dibelah ditimbang sebagai bobot karkas kiri dan kanan. Bagian karkas kanan diambil dan dibagi menjadi delapan potongan komersial yaitu potongan leher (neck), bahu (shoulder), paha depan (shank) rusuk dada (rack), dada (breast), pinggang (loin), paha belakang (leg) dan lipatan paha (flank) (Badan Standariasi Nasional 2008). Selanjutnya dilakukan pengukuran luas urat daging mata rusuk pada potongan loin yaitu pada permukaan rib eye yang terletak diantara rusuk ke-12 dan 13. Potongan-potongan komersial tersebut selanjutnya ditimbang dan dilakukan diseksi antara jaringan tulang, otot dan lemak. Tulang, otot dan lemak yang telah diseksi ditimbang untuk mendapatkan bobot tulang, otot dan lemak pada masing-masing potongan komersial karkas.

\section{Peubah yang Diamati}

Peubah yang diamati dalam penelitian ini meliputi bobot potong, bobot karkas, persentase karkas, luas urat daging mata rusuk, konformasi karkas, komposisi jaringan karkas dan distribusi jaringan karkas pada potongan komersial karkas.

Analisis Data
Penelitian ini menggunakan Rancangan Acak Lengkap (RAL) pola faktorial $2 \times 2$ dengan lima kali ulangan. Faktor perlakuan I adalah pakan (Indigofera zollingeriana dan konsentrat komersial) dan faktor perlakuan II adalah sistem pemeliharaan (sistem pemeliharaan intensif dan semi intensif). Data hasil penelitian dianalisis menggunakan ANCOVA (Analysis Of Covariance) dengan bobot awal sebagai faktor koreksi. Apabila terdapat perbedaan yang nyata terhadap peubah yang diamati maka diuji lanjut menggunakan uji Least Square Means (Kaps dan Lamberson 2004).

\section{HASIL DAN PEMBAHASAN}

\section{Produktivitas Domba}

Produktivitas domba sangat erat kaitannya dengan manajemen pemeliharaan dan jenis pakan yang diberikan. Berdasarkan data pada (Tabel 2) menunjukkan bahwa terdapat pengaruh interaksi yang nyata $(\mathrm{P}<0.05)$ antara perlakuan pakan dan sistem pemeliharaan yang berbeda terhadap bobot potong domba. Pola interaksi antar perlakuan terhadap bobot potong dapat dilihat pada Gambar 1. Bobot potong paling tinggi terdapat pada perlakuan IKK dan berbeda nyata $(\mathrm{P}<0.05)$ dengan IIZ dan SIIZ, namun tidak berbeda nyata dengan SIKK. Sebaliknya bobot potong paling rendah terdapat pada IIZ dan tidak berbeda nyata dengan SIIZ.

Tingginya rataan bobot potong pada IKK diduga disebabkan oleh rendahnya pergerakan (exercise) domba akibat dari terbatasnya ruang gerak dalam kandang, sehingga tidak banyak energi yang digunakan untuk bergerak. Hal ini mengakibatkan kandungan nutrisi pakan yang dikonsumsi lebih banyak digunakan untuk pertumbuhan dan pertambahan bobot badan. Sedangkan rendahnya bobot potong pada IIZ diduga disebabkan oleh kandungan PK dan TDN dalam IZ yang tidak dapat dicerna secara optimal akibat dari tingginya serat kasar (SK) yang terkandungan. Pangestu et al. (2018) menyatakan bahwa pakan yang mengandung SK yang tinggi dapat menurunkan tingkat kecernaan dari kandungan nutrisi yang lain, karena kandungan zat gizi yang seharusnya dicerna terikat oleh komponen serat kasar (selulosa) hingga terbuang bersama ekskreta.

Rataan bobot dan persentase karkas domba pada perlakuan KK sebesar $9.20 \mathrm{~kg}$ dan $41.08 \%$ nyata lebih tinggi $(\mathrm{P}<0.05)$ dibandingkan dengan pemberian pakan IZ yaitu $7.67 \mathrm{~kg}$ dan $37.96 \%$. Hasil ini terkait dengan rataan bobot potong domba pada perlakuan KK yang lebih tinggi. Hal ini sesuai dengan pernyataan Zubir et al. (2011) bahwa bobot potong sangat berpengaruh terhadap produksi karkas dan persentase karkas. Bobot karkas senantiasa meningkat pada bobot potong yang berkisar antara 15 sampai $24.5 \mathrm{~kg}$ (Ahkmadi et al. 2005).

Luas urat daging mata rusuk yang didapatkan, menunjukkan bahwa tidak terdapat pengaruh yang nyata antar perlakuan terhadap luas uadamaru. Hal ini dikarenakan bobot potong domba pada penelitian ini masih tergolong rendah. Senada dengan yang dikemukakan oleh Johnson et al. (1997) bahwa penggunaan luas urat daging mata rusuk hanya terbatas pada karkas dengan bobot tinggi, dan tidak cocok digunakan untuk menduga proporsi perdagingan pada karkas dengan bobot rendah. Bila dilihat dari skor komformasi (butt shape), terlihat bahwa domba yang diberi KK sebesar 2.56 lebih tinggi $(\mathrm{P}<0.05)$ dibandingkan dengan perlakuan IZ yaitu 1.83. Kondisi ini terkait dengan bobot potong dan bobot karkas pada domba yang diberi pakan KK yang lebih tinggi. Hal ini sesuai dengan pernyataan Hafid 
Tabel 2. Produktivitas domba ekor tipis dengan pemberian pakan dan sistem pemeliharaan yang berbeda

\begin{tabular}{|c|c|c|c|c|}
\hline \multirow[t]{2}{*}{ Peubah } & \multirow[t]{2}{*}{ Sistem pemeliharaan } & \multicolumn{2}{|c|}{ Pemberian pakan } & \multirow[t]{2}{*}{ Rata-rata } \\
\hline & & KK & $\mathrm{IZ}$ & \\
\hline \multirow[t]{3}{*}{ Bobot potong $(\mathrm{kg})$} & SI & $21.49 \pm 0.57 \mathrm{bc}$ & $20.68 \pm 0.55 \mathrm{ab}$ & $21.09 \pm 0.39$ \\
\hline & I & $23.09 \pm 0.56 \mathrm{c}$ & $19.65 \pm 0.55 \mathrm{a}$ & $21.37 \pm 0.39$ \\
\hline & Rata-rata & $22.29 \pm 0.39$ & $20.17 \pm 0.39$ & \\
\hline \multirow[t]{3}{*}{ Bobot karkas (kg) } & SI & $8.93 \pm 0.37$ & $8.14 \pm 0.36$ & $8.54 \pm 0.25$ \\
\hline & I & $9.47 \pm 0.36$ & $7.19 \pm 0.36$ & $8.33 \pm 0.25$ \\
\hline & Rata-rata & $9.20 \pm 0.25 b$ & $7.67 \pm 0.25 \mathrm{a}$ & \\
\hline \multirow[t]{3}{*}{ Persentase karkas (\%) } & SI & $41.29 \pm 0.99$ & $39.39 \pm 0.97$ & $40.34 \pm 0.69$ \\
\hline & I & $40.88 \pm 0.98$ & $36.53 \pm 0.97$ & $38.70 \pm 0.69$ \\
\hline & Rata-rata & $41.08 \pm 0.68 b$ & $37.96 \pm 0.68 \mathrm{a}$ & \\
\hline \multirow[t]{3}{*}{ Luas urat daging mata rusuk $(\mathrm{cm} 2)$} & SI & $5.00 \pm 0.50$ & $5.23 \pm 0.49$ & $5.11 \pm 0.35$ \\
\hline & $\mathrm{I}$ & $4.93 \pm 0.49$ & $4.63 \pm 0.49$ & $4.78 \pm 0.35$ \\
\hline & Rata-rata & $4.96 \pm 0.34$ & $4.93 \pm 0.34$ & \\
\hline \multirow[t]{3}{*}{ Konformasi (skor) } & SI & $2.41 \pm 0.19$ & $2.03 \pm 0.18$ & $2.22 \pm 0.13$ \\
\hline & I & $2.72 \pm 0.18$ & $1.62 \pm 0.18$ & $2.17 \pm 0.13$ \\
\hline & Rata-rata & $2.56 \pm 0.13 b$ & $1.83 \pm 0.13 \mathrm{a}$ & \\
\hline
\end{tabular}

Keterangan : $\mathrm{IZ}=$ Indigofera zollingeriana $; \mathrm{KK}=$ konsentrat komersail. $\mathrm{SI}=$ semi intensif. $\mathrm{I}=$ intensif. Huruf kecil yang berbeda pada baris atau kolom yang sama menunjukkan berbeda nyata $(\mathrm{P}<0.05)$. Data dikoreksi berdasarkan rataan bobot awal pada 18.320 gram.

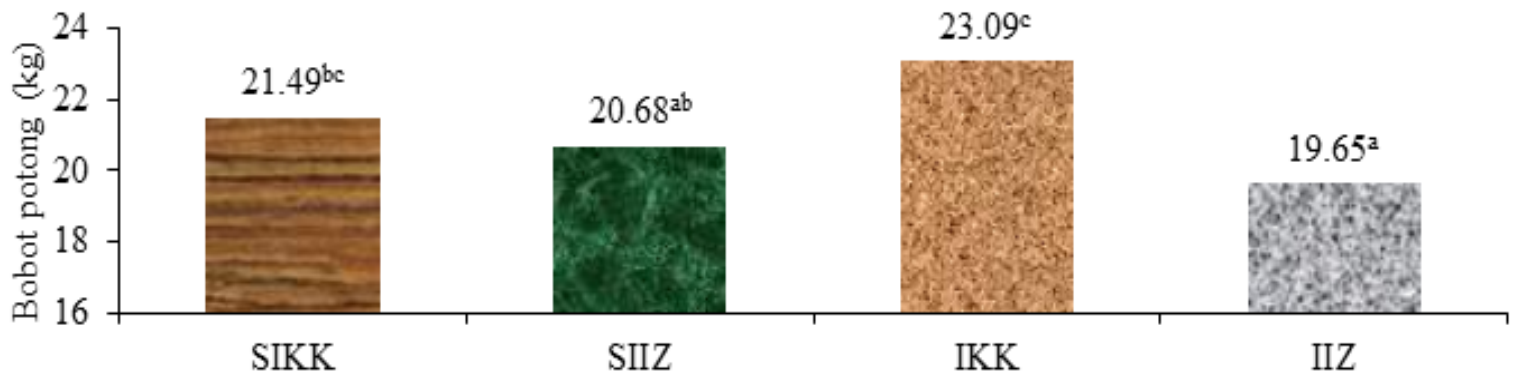

Gambar 1. Pengaruh interaksi antara pemberian pakan dan sistem pemeliharaan yang berbeda terhadap bobot potong domba.

dan Priyanto (2006) bahwa bobot potong dan bobot karkas ternak berhubungan dengan skor konformasi (butt shape) karkas.

\section{Komposisi Jaringan Karkas}

Data pada Tabel 3 menunjukkan bahwa terdapat pengaruh interaksi yang nyata $(\mathrm{P}<0.05)$ antara perlakuan pakan dan sistem pemeliharaan yang berbeda terhadap total otot domba. Total otot paling tinggi terdapat pada perlakuan IKK berbeda nyata dengan IIZ, namun berbeda tidak nyata dengan SIKK dan SIIZ. Sebaliknya bobot otot terendah terdapat pada IIZ dan berbeda nyata dengan perlakuan yang lain. Pola interkasi bobot otot (Gambar 2) membentuk pola interaksi yang hampir sama dengan pola interkasi pada bobot potong, dimana pada perlakuan IKK memiliki total otot tertinggi, namun ketika pakan yang digunakan adalah pakan IZ, menyebabkan penurunan total otot.

Rendahnya total otot pada IIZ disebabkan oleh rendahnya rataan bobot potong pada perlakuan tersebut. Subekti (2007) menyatakan bahwa kenaikan komponen karkas (otot, lemak dan tulang) dipengaruhi oleh kenaikan bobot potong dan bobot karkas. Bila dilihat dari persentase otot yang didapatkan, terlihat bahwa tidak terdapat pengaruh yang nyata antar perlakuan. Kondisi ini diduga disebabkan oleh pertumbuhan lemak tubuh yang belum optimal, sehingga belum dapat mempengaruhi persentase otot karkas. Hal ini sesuai dengan pernyataan Duljaman (2005) bahwa peningkatan persentase otot sangat tergantung dari bobot dan komponen karkas. Persentase otot dan tulang umumnya berbanding terbalik dengan bobot karkas, sedangkan persentase lemak berbanding lurus (Zubir et al. 2011).

Domba yang diberi pakan KK menunjukkan rataan bobot dan persentase lemak yang lebih tinggi $(\mathrm{P}>0.05)$ dibandingkan dengan domba yang diberi pakan IZ. Hal ini disebabkan karena domba yang diberi pakan KK memiliki bobot potong dan bobot karkas yang lebih tinggi, sehingga menyebabkan proporsi dan persentase lemak tubuh juga meningkat. Hal ini sesuai dengan pernyataan Aslimah et al. (2014) bahwa tingkat konsumsi, bobot tubuh 
Jatnika et al.

Jurnal Ilmu Produksi dan Teknologi Hasil Peternakan 7 (3): 111-119

Tabel 3. Rataan bobot dan persentase jaringan karkas domba ekor tipis dengan pemberian pakan dan sistem pemeliharaan yang berbeda

\begin{tabular}{|c|c|c|c|c|}
\hline \multirow[t]{2}{*}{ Peubah } & \multirow[t]{2}{*}{ Sistem pemeliharaan } & \multicolumn{2}{|c|}{ Pemberian pakan } & \multirow[t]{2}{*}{ Rata-rata } \\
\hline & & KK & $\mathrm{IZ}$ & \\
\hline \multirow[t]{3}{*}{ Otot $(\mathrm{Kg})$} & SI & $2.390 \pm 0.09 \mathrm{~b}$ & $2.296 \pm 0.09 b$ & $2.343 \pm 0.06$ \\
\hline & I & $2.551 \pm 0.09 \mathrm{~b}$ & $1.950 \pm 0.09 \mathrm{a}$ & $2.250 \pm 0.06$ \\
\hline & Rata-rata & $2.471 \pm 0.06$ & $2.123 \pm 0.06$ & \\
\hline \multirow[t]{3}{*}{ Lemak (Kg) } & SI & $0.663 \pm 0.09$ & $0.326 \pm 0.09$ & $0.495 \pm 0.06$ \\
\hline & I & $0.711 \pm 0.09$ & $0.428 \pm 0.09$ & $0.570 \pm 0.06$ \\
\hline & Rata-rata & $0.687 \pm 0.06 \mathrm{~b}$ & $0.377 \pm 0.06 \mathrm{a}$ & \\
\hline \multirow[t]{3}{*}{ Tulang (Kg) } & SI & $1.052 \pm 0.15$ & $1.160 \pm 0.14$ & $1.106 \pm 0.10$ \\
\hline & I & $1.030 \pm 0.14$ & $0.824 \pm 0.14$ & $0.927 \pm 0.10$ \\
\hline & Rata-rata & $1.041 \pm 0.10$ & $0.992 \pm 0.10$ & \\
\hline \multirow[t]{3}{*}{ Otot $(\%)$} & SI & $58.31 \pm 1.22$ & $61.25 \pm 1.18$ & $59.78 \pm 0.84$ \\
\hline & I & $57.76 \pm 1.20$ & $58.95 \pm 1.18$ & $58.36 \pm 0.84$ \\
\hline & Rata-rata & $58.04 \pm 0.84$ & $60.10 \pm 0.84$ & \\
\hline \multirow[t]{3}{*}{ Lemak (\%) } & SI & $15.29 \pm 1.60$ & $8.67 \pm 1.56$ & $11.98 \pm 1.11$ \\
\hline & I & $15.43 \pm 1.58$ & $12.83 \pm 1.56$ & $14.13 \pm 1.11$ \\
\hline & Rata-rata & $15.36 \pm 1.10 \mathrm{~b}$ & $10.75 \pm 1.10 \mathrm{a}$ & \\
\hline \multirow[t]{3}{*}{ Tulang (\%) } & SI & $25.13 \pm 3.46$ & $31.11 \pm 3.37$ & $28.12 \pm 2.40$ \\
\hline & I & $23.29 \pm 3.41$ & $24.87 \pm 3.36$ & $24.08 \pm 2.40$ \\
\hline & Rata-rata & $24.21 \pm 2.38$ & $27.99 \pm 2.38$ & \\
\hline
\end{tabular}

Keterangan : $\mathrm{IZ}=$ Indigofera zollingeriana $; \mathrm{KK}=$ konsentrat komersail. $\mathrm{SI}=$ semi intensif. $\mathrm{I}=$ intensif. Huruf kecil yang berbeda pada baris atau kolom yang sama menunjukkan berbeda nyata $(\mathrm{P}<0.05)$, data dikoreksi berdasarkan rataan bobot awal pada 18.320 gram.

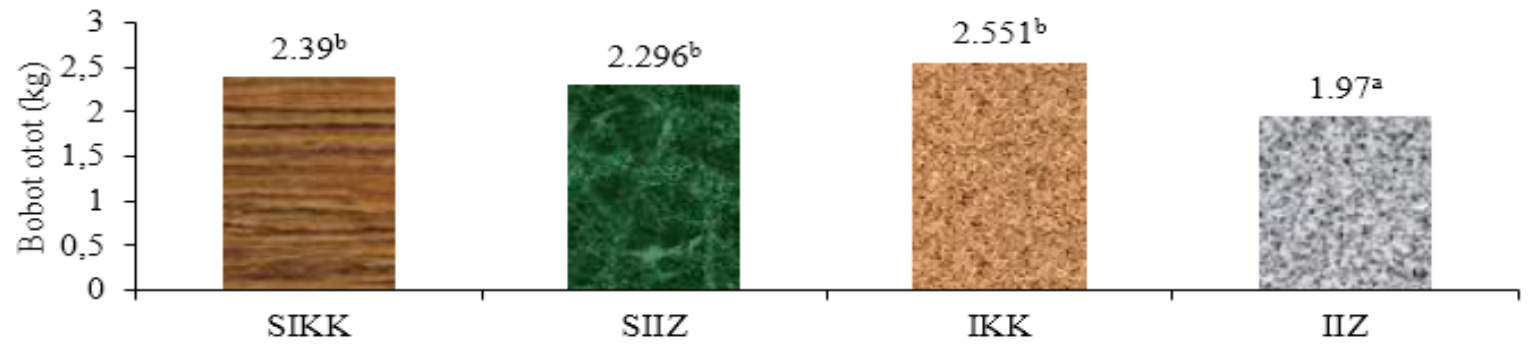

Gambar 2. Pengaruh interaksi antara pemberian pakan dan sistem pemeliharaan yang berbeda terhadap bobot otot domba.

dan berat lemak memiliki hubungan yang sangat erat. Semakin tinggi bobot potong pada ternak maka akan diikuti oleh peningkatan bobot komponen-komponen fisik karkas (Asari et al. 2018). Data pada (Tabel 3) menunjukkan bahwa tidak terdapat pengaruh yang nyata antara semua perlakuan terhadap bobot dan persentase tulang. Hal ini disebabkan karena domba yang dipotong sudah mendekati umur dewasa, sehingga pertumbuhan tulang sudah mulai melambat sedangkan pertumbuhan otot dan lemak tubuh semakin meningkat. Thomson et al. (1979) menyatakan bahwa tulang merupakan komponen karkas yang tumbuh lebih awal atau masak dini dibandingkan dengan jaringan otot dan lemak.

\section{Distribusi otot pada potongan komersial karkas}

Distribusi otot dan lemak pada potongan komersial karkas disajikan pada Tabel 4. Data tabel 4 menunjukkan bahwa terdapat interkasi antar perlakuan terhadap bobot otot shoulder. Pola interaksi bobot otot shoulder dapat diihat pada Gambar 3. Bobot otot shoulder tertinggi terdapat pada IKK berbeda nyata dengan IIZ, namun tidak berbeda nyata dengan SIKK dan SIIZ. Sebaliknya bobot otot shoulder paling rendah terdapat pada IIZ berbeda nyata dengan perlakuan yang lain. Hal ini menunjukkan bahwa bobot otot shoulder pada perlakuan KK baik dengan pemeliharaan semi intensif maupun intensif memiliki bobot otot shoulder yang relatif sama, sedangkan bobot otot shoulder pada perlakuan IZ akan meningkat bila dipelihara secara semi intensif dan menurun bila dipelihara secara intensif. Bila ditinjau dari perlakuan pakan yang diberikan, terlihat bahwa domba yang diberi pakan KK memiliki bobot otot breast leg dan loin yang lebih tinggi $(\mathrm{P}<0.05)$ dibandingkan dengan domba yang diberi pakan IZ. Kondisi ini terkait dengan rataan bobot total otot pada masing-masing perlakuan (Tabel 3). Hal ini sesuai dengan pernyataan Zubir et al. (2011) bahwa 
Jatnika et al.

Jurnal Ilmu Produksi dan Teknologi Hasil Peternakan 7 (3): 111-119

Tabel 4. Distribusi otot pada potongan komersial karkas domba ekor tipis dengan pemberian pakan dan sistem pemeliharaan yang berdeda.

\begin{tabular}{|c|c|c|c|c|}
\hline \multirow[t]{2}{*}{ Peubah (g) } & \multirow[t]{2}{*}{ Sistem pemeliharaan } & \multicolumn{2}{|c|}{ Pemberian pakan } & \multirow[t]{2}{*}{ Rata-rata } \\
\hline & & KK & $\mathrm{IZ}$ & \\
\hline \multirow[t]{3}{*}{ Neck } & SI & $199.44 \pm 22.29$ & $169.50 \pm 21.69$ & $184.47 \pm 15.47$ \\
\hline & I & $218.50 \pm 21.95$ & $175.74 \pm 21.68$ & $197.12 \pm 15.47$ \\
\hline & Rata-rata & $208.97 \pm 15.35$ & $172.62 \pm 15.35$ & \\
\hline \multirow[t]{3}{*}{ Shoulder } & SI & $436.40 \pm 26.28 b$ & $454.81 \pm 25.67 \mathrm{~b}$ & $445.61 \pm 18.31$ \\
\hline & I & $471.19 \pm 25.98 b$ & $328.78 \pm 25.67 \mathrm{a}$ & $399.98 \pm 18.31$ \\
\hline & Rata-rata & $453.80 \pm 18.17$ & $391.79 \pm 18.17$ & \\
\hline \multirow[t]{3}{*}{ Rack } & SI & $158.89 \pm 14.76$ & $157.25 \pm 14.37$ & $158.07 \pm 10.25$ \\
\hline & I & $161.60 \pm 14.53$ & $116.04 \pm 14.36$ & $138.82 \pm 10.25$ \\
\hline & Rata-rata & $160.24 \pm 10.16$ & $136.65 \pm 10.16$ & \\
\hline \multirow[t]{3}{*}{ Breast } & SI & $203.09 \pm 10.12$ & $177.11 \pm 9.85$ & $190.10 \pm 7.02$ \\
\hline & I & $211.07 \pm 9.96$ & $150.52 \pm 9.84$ & $180.79 \pm 7.02$ \\
\hline & Rata-rata & $207.08 \pm 6.97 b$ & $163.81 \pm 6.97 \mathrm{a}$ & \\
\hline \multirow[t]{3}{*}{ Shank } & SI & $219.94 \pm 13.33$ & $211.88 \pm 12.97$ & $215.91 \pm 9.25$ \\
\hline & I & $234.50 \pm 13.13$ & $189.67 \pm 12.97$ & $212.08 \pm 9.25$ \\
\hline & Rata-rata & $227.22 \pm 9.18$ & $200.77 \pm 9.18$ & \\
\hline \multirow[t]{3}{*}{ Leg } & SI & $932.93 \pm 44.47$ & $892.81 \pm 43.28$ & $918.87 \pm 30.87$ \\
\hline & I & $996.11 \pm 43.79$ & $788.93 \pm 43.27$ & $892.52 \pm 30.87$ \\
\hline & Rata-rata & $964.52 \pm 30.62 b$ & $840.87 \pm 30.62 \mathrm{a}$ & \\
\hline \multirow[t]{3}{*}{ Loin } & SI & $202.67 \pm 12.34$ & $185.31 \pm 12.01$ & $193.99 \pm 8.56$ \\
\hline & I & $221.48 \pm 12.15$ & $163.32 \pm 12.01$ & $192.40 \pm 8.56$ \\
\hline & Rata-rata & $212.07 \pm 8.50 b$ & $174.32 \pm 8.50 \mathrm{a}$ & \\
\hline \multirow[t]{3}{*}{ Flank } & SI & $37.79 \pm 6.35$ & $47.46 \pm 6.18$ & $42.62 \pm 4.41$ \\
\hline & I & $37.53 \pm 6.26$ & $37.80 \pm 6.18$ & $37.67 \pm 4.41$ \\
\hline & Rata-rata & $37.66 \pm 4.37$ & $42.63 \pm 4.37$ & \\
\hline
\end{tabular}

Keterangan : $\mathrm{IZ}=$ Indigofera zollingeriana $; \mathrm{KK}=$ konsentrat komersail. $\mathrm{SI}=$ semi intensif. $\mathrm{I}=$ intensif. Huruf kecil yang berbeda pada baris atau kolom yang sama menunjukkan berbeda nyata $(\mathrm{P}<0.05)$, data dikoreksi berdasarkan rataan bobot awal pada 18.320 gram.

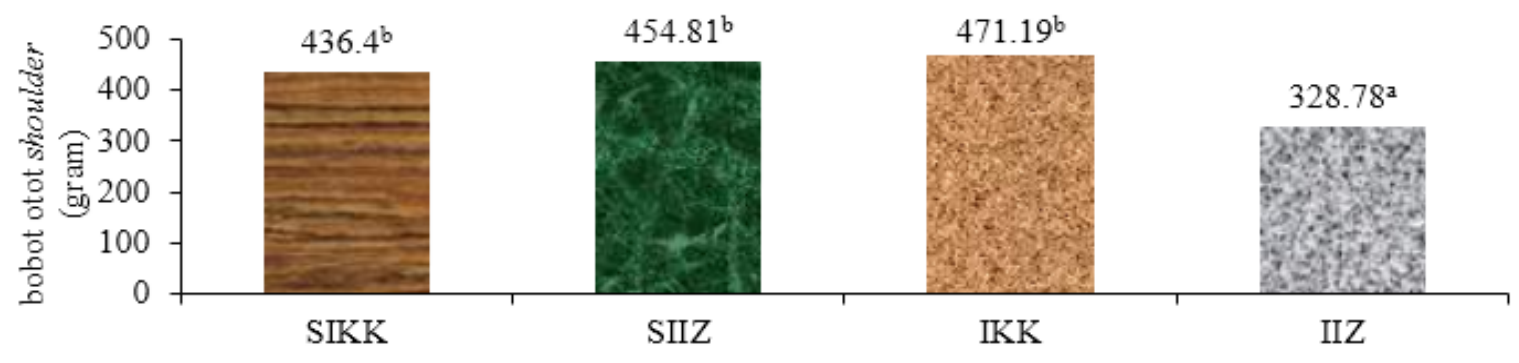

Gambar 3. Pengaruh interaksi antara pemberian pakan dan sistem pemeliharaan yang berbeda terhadap bobot otot shoulder

perbedaan bobot otot akan diikuti oleh perbedaan bobot pada potongan komersialnya.

\section{Distribusi lemak pada potongan komersial karkas}

Berdasarkan data pada Tabel 5, menunjukkan bahwa bahwa domba yang diberi pakan KK memiliki bobot lemak yang nyata lebih tinggi $(\mathrm{P}<0.05)$ dibadingkan dengan pemberian IZ pada potongan neck, rack, breast, shank, leg dan loin. Hal ini menunjukkan bahwa secara umum pemberian KK menyebabkan peningkatan proporsi lemak pada masing-masing potongan komersial karkas. Tingginya proporsi lemak pada perlakuan ini sangat erat kaitannya dengan bobot potong, bobot karkas, bobot total lemak serta bobot partisi lemak subkutan dan intermuskuler. Hal ini seiring dengan pernyataan Duljaman (2005) bahwa peningkatan bobot tubuh ternak akan diikuti oleh peningkatan bobot karkas dan bobot lemak. Perbedaan 
Jatnika et al.

Jurnal Ilmu Produksi dan Teknologi Hasil Peternakan 7 (3): 111-119

Tabel 5. Distribusi lemak pada potongan komersial karkas domba ekor tipis dengan pemberian pakan dan sistem pemeliharaan yang berdeda

\begin{tabular}{|c|c|c|c|c|}
\hline \multirow[t]{2}{*}{ Peubah (g) } & \multirow[t]{2}{*}{ Sistem pemeliharaan } & \multicolumn{2}{|c|}{ Pemberian pakan } & \multirow[t]{2}{*}{ Rata-rata } \\
\hline & & KK & $\mathrm{IZ}$ & \\
\hline \multirow[t]{3}{*}{ Neck } & SI & $59.53 \pm 9.71$ & $16.11 \pm 9.45$ & $37.82 \pm 6.74$ \\
\hline & I & $34.29 \pm 9.56$ & $25.38 \pm 9.45$ & $29.83 \pm 6.74$ \\
\hline & Rata-rata & $46.91 \pm 6.68 b$ & $20.74 \pm 6.68 \mathrm{a}$ & \\
\hline \multirow[t]{3}{*}{ Shoulder } & SI & $68.49 \pm 12.53$ & $46.64 \pm 12.19$ & $57.57 \pm 8.70$ \\
\hline & I & $81.39 \pm 12.34$ & $55.61 \pm 12.19$ & $68.50 \pm 8.70$ \\
\hline & Rata-rata & $74.94 \pm 8.63$ & $51.13 \pm 8.63$ & \\
\hline \multirow[t]{3}{*}{ Rack } & SI & $54.07 \pm 13.88$ & $17.80 \pm 13.51$ & $35.93 \pm 9.63$ \\
\hline & I & $71.73 \pm 13.67$ & $42.30 \pm 13.50$ & $57.02 \pm 9.63$ \\
\hline & Rata-rata & $62.90 \pm 9.56 b$ & $30.05 \pm 9.56 \mathrm{a}$ & \\
\hline \multirow[t]{3}{*}{ Breast } & SI & $92.28 \pm 17.82$ & $41.62 \pm 17.24$ & $66.95 \pm 12.37$ \\
\hline & I & $112.87 \pm 17.55$ & $49.27 \pm 17.34$ & $81.07 \pm 12.37$ \\
\hline & Rata-rata & $102.57 \pm 12.27 b$ & $45.45 \pm 12.27 \mathrm{a}$ & \\
\hline \multirow[t]{3}{*}{ Shank } & SI & $29.87 \pm 4.50$ & $17.73 \pm 4.38$ & $23.80 \pm 3.12$ \\
\hline & I & $15.90 \pm 4.38$ & $15.90 \pm 4.38$ & $19.28 \pm 3.12$ \\
\hline & Rata-rata & $26.27 \pm 3.10 b$ & $16.81 \pm 3.10 \mathrm{a}$ & \\
\hline \multirow[t]{3}{*}{ Leg } & SI & $117.20 \pm 19.16$ & $66.07 \pm 18.65$ & $91.63 \pm 13.30$ \\
\hline & I & $138.37 \pm 18.87$ & $105.82 \pm 18.65$ & $122.10 \pm 13.30$ \\
\hline & Rata-rata & $127.79 \pm 13.20 \mathrm{~b}$ & $85.94 \pm 13.20 \mathrm{a}$ & \\
\hline \multirow[t]{3}{*}{ Loin } & SI & $60.82 \pm 11.15$ & $20.78 \pm 10.85$ & $40.80 \pm 7.74$ \\
\hline & I & $70.25 \pm 10.98$ & $31.37 \pm 10.85$ & $50.81 \pm 7.74$ \\
\hline & Rata-rata & $65.54 \pm 7.68 b$ & $26.07 \pm 7.68 \mathrm{a}$ & \\
\hline \multirow[t]{3}{*}{ Flank } & SI & $19.42 \pm 5.12$ & $11.76 \pm 4.98$ & $15.59 \pm 3.55$ \\
\hline & I & $18.91 \pm 5.04$ & $7.43 \pm 4.98$ & $13.17 \pm 3.55$ \\
\hline & Rata-rata & $19.16 \pm 3.52$ & $9.60 \pm 3.52$ & \\
\hline
\end{tabular}

Keterangan : IZ = Indigofera zollingeriana ; KK = konsentrat komersail. SI = semi intensif. $\mathrm{I}=$ intensif. Huruf kecil yang berbeda pada baris atau kolom yang sama menunjukkan berbeda nyata $(\mathrm{P}<0.05)$, data dikoreksi berdasarkan rataan bobot awal pada 18.320 gram

proporsi lemak pada masing-masing potongan komersial karkas tergantung dari distribusi dan deposisi partisi lemak (subkutan dan intermuskuler). Lemak subkutan umumnya didistribusikan pada potongan leg, loin, dan flank, sedangkan lemak intermuskuler dideposisikan pada potongan shoulder, rack, neck dan shank (Dagong 2012).

\section{KESIMPULAN}

Domba yang diberi Indigofera zollingeriana memiliki bobot potong, bobot karkas, bobot lemak yang lebih rendah dibandingkan dengan domba yang diberi konsentrat komersial, namun dengan pemeliharaan secara semi intensif memiliki bobot dan persentase otot yang relatif sama dengan domba yang diberi konsentrat komersial.

\section{DAFTAR PUSTAKA}

Abdullah, L.N.R., Kumalasari., Nahrowi, \& Suharlina. 2010. Pengembangan Produk Hay, Tepung dan Pelet Daun Indigofera $s p$ sebagai alternatif sumber protein murah pakan kambing perah. Laporan Penelitian. Fakultas Peternakan IPB.

Akhmadi, D., E. Purbowati, \& R. Adiwinarti. 2005. Persentase "edible porton" domba yang diberi ampas tahu kering dengan aras yang berbeda. J.Indon. Trop. Anim.Agric. 30(4) Desember 2005.

Ashari, M., R. A. Suhardiani, \& R. Andriati. 2018. Produksi dan komposisi fisik karkas domba ekor gemuk yang dipelihara secara tradisional di Lombok. Jurnal Ilmu dan Teknologi Peternakan Indonesia. Juli 2018 ISSN: 2460-6669. 4 (1): 191-198.

Aslimah, S., Yamin M, \& Astuti DA. 2014. Produktivitas karkas domba garut jantan pada pemberian jenis pakan dan waktu yang berbeda. Jurnal Ilmu Produksi dan Teknologi Hasil Peternakan. Januari 2014. ISSN 23032227. 2 (1): 251-256. 
Badan Standardisasi Nasional Indonesia. 2008. Mutu karkas dan daging kambing/domba. Standar Nasional Indonesia. 3925: Jakarta.

Baihaqi, M., S. Rahayu., M. Duljaman, \& Nurmalasari. 2013. Komposisi Jaringan Karkas Domba Ekor Tipis Yang Diberi Pakan Hijauan Pada Periode AIZir Penggemukan. ISSN 2303-2227. Vol. 01 No. 1, Januari 2013. Hlm:8-14.

Corcoran, K., A. Bernues., E. Manruque., T. Pacchioli., R. Baines, \& Boutonnet JP. 2001. Current Consumer Attitudes Towards Lamb and Beef in Erope. In: Proceedings of Production Systems and Product Quality in Sheep and Goats. Options Mediteranneesserie-A-Seminares - Mediterranneens, 46 :75 -79.

Dagong, M.I.A., R. Herman., C. Sumantri., R.R. Noor, \& M. Yamin. 2012. Karakteristik karkas dan sifat fisik daging domba ekor tipis (DET) berdasarkan variasi genotip gen kalpastatin (CAST) (Lokus intron 5-ekson 6). JITV. Th. 2012: 17(1): 13-24.

Duljaman, M. 2005. Kualitas karkas domba yang diberi pakan rumput kering dan ditambah ampas tahu. J.Indon. Trop.Anim.Agric. Juni 2005. 30(2).

Hafid, H.H., \& R. Priyanto. 2006. Pengaruh konformasi butt shape terhadap karakteristik karkas sapi brahman cross pada beberapa klasifikasi jenis kelamin. Media Peternakan, Desember 2006. ISSN 0126-0472. 29(3): 162-168

Hassen, A., N.F.G. Rethman., V. Niekerk, \& T.J. Tjelele. 2007. Influence of season/year and species on chemical composition and in vitro digestibility of five indigofera accessions. J. Anim. Feed Sci Tech. 136: 312-322.

Herman, R. 1993. Perbandingan pertumbuhan, komposisi tubuh, dan karkas antara domba priangan dan ekor gemuk. [disertasi]. Bogor (ID): Sekolah Pascasarjana, Institut Pertanian Bogor.

Jarmuji. 2010. Produksi susu induk terhadap pengaruh pertambahan bobot badan, bobot sapih dan daya hidup anak domba ekor tipis jawa periode prasapih. Jurnal Sain Peternakan Indonesia. Januari-Juni 2010. ISSN 1978-3000. 5(1).

Johnson, P.L., R.W. Purchas., J.C. Mcewan, \& H.T. Blair. 2005. Carcass composition and meat quality differences between pasture-reared ewe and ram lambs. Meat Sci. 71: 383-391.

Johnson, E.R., R. Priyanto, \& R.G. Taylor. 1997. Investigation into the accuracy of prediction of beef carcass composition using subcutaneous fat thickness and carcass wight II. Improving The Accuracy Of Prediction. J. Meat Sci. 46 (2): 193-200.
Majlis Ulama' Indonesia (MUI). 2009. Standar sertifikat penyembelihan halal. Wadah Musyawarah Para Ulama' Zu'ama dan Cendikiawan Muslim: Jakarta.

Pangestu, G.A., R.I. Pujaningsih., \& I. Mangisah. 2018. pengaruh ransum yang mengandung limbah tauge fermentasi terhadap kecernaan serat kasar, protein kasar dan energi metabolis pada itik lokal fase starter. Jurnal Ilmiah Peternakan Terpadu. Maret 2018. 6(1): 77-82.

Pethick, D.W, \& J.B. Rowe. 1996. The effect of nutrition and exercise on carcass parameters and the level of glycogen in skeletal muscle of merino sheep. Au t. J. Agric. Res., 1996. 4(7): 525-37

Rodrigues, S.V., Cadaves, \& A. Teixeira. 2006. Breed and maturity effects on churra galega bragancana and suffolk lamb carcass characteristics: killing-out proportion and composition. Meat Sci. 72: 288-293.

Santos, A.C.G.D., M. Yamin., R. Priyanto, \& H. Maheshwari. 2019. Respon Fisiologi Domba pada Sistem Pemeliharaan dan Pemberian Jenis Konsentrat Berbeda. ISSN 2303-2227 eISSN 2615-594X. Vol. 07 No. 1 Januari 2019

Subekti, E. 2007. Pengaruh jenis kelamin dan bobot potong terhadap kinerja produksi domba lokal. J. Ilmu-Ilmu Pertanian. 3(1): 59-66.

Sudaryanto, B, \& D. Priyanto. 2008. Degradasi padang penggembalaan. Balai Penelitian Ternak.

Taringan, A., L. Abdullah., S.P. Ginting, \& I.G. Permana., 2010. Produksi dan komposisi nutrisi serta kecernaan In Vitro Indigofera $\mathrm{sp}$ pada interval dan tinggi pemotongan berbeda. JITV. 15(2): 188-195.

Thomson, J.M., K.D. Atkins, \& A.R. Gelmour. 1979. Carcass characteristics of heavy weight crossbreed lamb III. Distribution of Subcutaneous Fat Intermusculaer Fat, Muscle And Bone In The Carcass, Austr. Res. 30:1215-1223

Wijaya, G.H., M. Yamin., H. Nuraini., A. Esfandiari. 2016. Performans Produksi dan Profil Metabolik Darah Domba Garut dan Jonggol yang Diberi Limbah Tauge dan Omega-3. pISSN: 1411-8327; eISSN: 2477-5665. Juni 2016 Vol. 17 No. 2 : 246-256

Zubir., R. Priyanto., E. Gurnadi, W. Manalu, \& H.M. Winugroho. 2011. Produksi dan komposisi fisik karkas domba jantan priangan yang disuplementasi peptida pasak bumi (Eurycoma longifolia Jack). JITV. 16(3): 184-193. 